\title{
Development of an anaerobic hydrogen and methane fermentation system for kitchen waste biomass utilization
}

\author{
Noriko Osaka ${ }^{1}$, Kohki Nagai ${ }^{2}$, Shiho Mizuno ${ }^{2}$, Makiko Sakka $^{3}$, and Kazuo Sakka ${ }^{3}$ \\ ${ }^{1}$ Fundamental Technology Department, Technology Research Institute, Tokyo Gas Co., LTD, 1-7-7, \\ Suehiro-cho, Tsurumi-ku, Yokohama-City, Kanagawa 230-0045, Japan \\ ${ }^{2}$ Fundamental Research Department, Technical Research Institute, Toho Gas Co., LTD, 507-2 Shinpo- \\ Machi, Tokai-City, Aichi 476-8501, Japan \\ ${ }^{3}$ Applied Microbiology Laboratory, Graduate School of Bioresources, Mie University, \\ 1577 Kurima-Machiyacho, Tsu-City, Mie 514-8507, Japan \\ * Corresponding author. Tel: +81 45500 8769, Fax: +45 500 8790, E-mail: nosaka@tokyo-gas.co.jp
}

\begin{abstract}
Utilization of kitchen waste as biomass resources has been of growing importance in urban areas of Japan. Present-day standards have set much sterner target recycling rates especially for kitchen waste from food industry, e.g. restaurants and food retail dealers. Aiming at high-efficiency energy recovery from kitchen waste, we have developed a two-step anaerobic fermentation system for generating hydrogen and methane. Biohydrogen is produced in the initial fermentation step by thermophilic microbiota mainly consisting of Clostridium species. Then, residues such as organic acids are converted into bio-methane in the second methane fermentation step. By proficiently combining these two fermentation steps, high system efficiency can be achieved. Optimum operating conditions have been found in the laboratory test of hydrogen fermentation operated over 300 days using artificial kitchen waste.
\end{abstract}

Keywords: Biomass, Methane fermentation, Hydrogen fermentation

\section{Nomenclature}

TS Total solid. ..$\%$

VFA Volatile fatty acid
COD Chemical oxygen demand $m g / L$ HRT Hydraulic retention time days

\section{Introduction}

Energy from biomass is the promising renewable energy. In Japan, "Biomass Japan broad strategic view" was determined in December 2002. The concrete target value of greenhouse gas discharge reduction was set to develop the recycling society. We are demanded to plan maximum profit utilization of biomass. In particular of them, it needs great amount of energy as oil and gas to incinerate sewage sludge and kitchen wastes which content much water. Great amount of energy as oil and gas is particularly required to incinerate sewage sludge and kitchen wastes, which contain much water. The realization of fermentation technology recovering energy from biomass reduces $\mathrm{CO}_{2}$ emission from the garbage disposal. $\mathrm{H}_{2}$ produced from biomass $\left(\mathrm{Bio}-\mathrm{H}_{2}\right)$ is especially expected as one of the important energy sources in the future plan of hydro-energy. We know bacteria fermenting carbohydrates as glucose and cellulose. The bacteria make organic acids in their metabolic process. $\mathrm{H}_{2}-\mathrm{CH}_{4}$ fermentation is known as an efficient energy recovery system because organic acids can be used for substrate of fermented methane. Methane fermentation is available for many carbonic wastes, however, HRT is long. Therefore, pre-treatment to oxidize carbonic wastes in the fermentation process is needed to shorten HRT. Some trial tests have been conducted to apply $\mathrm{H}_{2}$ fermentation as pre-treatment for acceleration of energy generation. 


\section{Materials and methods}

\subsection{Materials}

Our research is aimed for the realization of efficient recycle and disposal system. We used artificial kitchen wastes as the substrate in our lab. In the pilot plant, the kitchen waste discharged from our canteen and dog foods are made use of raw materials. The composition and contents of substrates in the laboratory test are as follows. (Table1, 2, 3) The ratio of carbon and nitrogen is about 15. It is slightly lower than ideal condition for $\mathrm{CH}_{4}$ fermentation. Table4 shows materials in the pilot plant. These materials are diluted and regulated the ratio of total solid. (Table5)

Table 1 Composition of the material as artificial kitchen waste in the laboratory test

\begin{tabular}{lrrrc}
\hline & $\begin{array}{c}\text { Shredded } \\
\text { vegetable }\end{array}$ & Minced meat & Boiled fish & Cooked Rice \\
\hline Weight ratio (wt \%) & 86.7 & 3.3 & 3.3 & 6.7 \\
\hline
\end{tabular}

Table 2 Contents of the material as artificial kitchen waste in the laboratory test

\begin{tabular}{llllll}
\hline Content & Water & Protein & Oil & $\begin{array}{l}\text { Carbohydra } \\
\text { tes }\end{array}$ & Ash \\
\hline Weight ratio (wt \%) & 77.8 & 4.4 & 2 & 15 & 0.8 \\
\hline
\end{tabular}

Table 3 Ratio of elements of the material as artificial kitchen waste in the laboratory test

\begin{tabular}{lllllll}
\hline Element & $\mathrm{C}$ & $\mathrm{H}$ & $\mathrm{N}$ & $\mathrm{S}$ & $\mathrm{O}$ & Ash \\
\hline$(\%)$ & 45.5 & 7.3 & 3.2 & 0.1 & 41.2 & 2.7 \\
\hline
\end{tabular}

Table 4 Composition of the material for the plant test

\begin{tabular}{ccc}
\hline & Kitchen waste & Dog food \\
\hline Weight $(\mathrm{kg})$ & 20 & 12 \\
\hline
\end{tabular}

Table 5 TS in the diluted materials

\begin{tabular}{ccc}
\hline & Laboratory & Pilot plant \\
\hline TS (\%) & 7.5 & 6.5 \\
\hline
\end{tabular}

\subsection{Methodology}

\subsection{1. $\mathrm{H}_{2}-\mathrm{CH}_{4}$ fermentation}

The metabolism of $\mathrm{H}_{2}-\mathrm{CH}_{4}$ fermentation is as follows. Bacteria generate $\mathrm{H}_{2}$ on two pathways concerning glucose as carbohydrate in kitchen waste. Much hydrogen can be generated from glucose in the pathway (1). The generation rate of hydrogen is $4 \mathrm{~mol} / 1 \mathrm{~mol}$-glucose, and that of acetic acid is $2 \mathrm{~mol} / 1 \mathrm{~mol}$-glucose.

$$
\begin{aligned}
& \mathrm{C}_{6} \mathrm{H}_{12} \mathrm{O}_{6}+2 \mathrm{H}_{2} \mathrm{O} \rightarrow 4 \mathrm{H}_{2}+2 \mathrm{CO}_{2}+2 \mathrm{CH}_{3} \mathrm{COOH} \\
& \mathrm{C}_{6} \mathrm{H}_{12} \mathrm{O}_{6} \rightarrow 2 \mathrm{H}_{2}+2 \mathrm{CO}_{2}+\mathrm{CH}_{3} \mathrm{CH}_{2} \mathrm{CH}_{2} \mathrm{COOH}
\end{aligned}
$$

In the case of $\mathrm{CH} 4$ fermentation, acetic acid and $\mathrm{H} 2$ are the substrate for generating $\mathrm{CH} 4$. There are 3 main pathways as follows. $70 \%$ of Bio- $\mathrm{CH} 4$ is generated as the deconstruction of acetic acid in the pathway (3), and about $30 \%$ of Bio-CH4 is generated in the pathway (4). The pathway (5) is a rare case.

$$
\begin{aligned}
& \mathrm{CH}_{3} \mathrm{COOH} \rightarrow \mathrm{CH}_{4}+\mathrm{CO}_{2} \\
& 4 \mathrm{H}_{2}+\mathrm{CO}_{2}+\mathrm{H}_{2} \mathrm{O} \rightarrow 4 \mathrm{H}_{2}+\mathrm{HCO}_{3}^{-}+\mathrm{H}^{+} \rightarrow \mathrm{CH}_{4}+3 \mathrm{H}_{2} \mathrm{O}
\end{aligned}
$$




$$
4 \mathrm{HCOOH} \rightarrow \mathrm{CH}_{4}+3 \mathrm{CO}_{2}+2 \mathrm{H}_{2} \mathrm{O}
$$

When we develop high-efficient $\mathrm{H}_{2}-\mathrm{CH}_{4}$ fermentation system, the pathway (1) and (3) should be activated.

A pre-treatment process is generally adopted in commercial plants to promote the methane fermentation.

In the process, carbohydrate is converted to organic acetic acids in the following pathway (6). The acetic acids are equivalent to $3 \mathrm{~mol}$ methane / 1 mol-glucose.

$\mathrm{C}_{6} \mathrm{H}_{12} \mathrm{O}_{6} \rightarrow 3 \mathrm{CH}_{3} \mathrm{COOH}$

Table 6 shows estimated calorific values of generated bio- $\mathrm{H}_{2}$ and bio- $\mathrm{CH}_{4} \cdot \mathrm{H}_{2}-\mathrm{CH}_{4}$ fermentation is more efficient than Acidizing- $\mathrm{CH}_{4}$ fermentation to recover energy.

Table 6 Calorific values of generated biogas on two pathways

\begin{tabular}{lc}
\hline & Calorie $[\mathrm{kJ} /$ mol-glucose $]$ \\
\hline Acidizing $-\mathrm{CH}_{4}$ fermen. & 2405 \\
\hline $\mathrm{H}_{2}$ fermen. $-\mathrm{CH}_{4}$ fermen. & 2570 \\
\hline
\end{tabular}

Representative bacteria of $\mathrm{H}_{2}$ fermentation include the Clostridium genus of the obligate anaerobe, and Escherichia coli of the facultative anaerobic bacterium. These bacteria have a weak property in concentration of organic acids, especially lactic acid. Acid generation bacteria are cultured in medium temperature and prefer neutrality to acidity not in thermal and aciditic environment. Therefore, it is most important to look for $\mathrm{H}_{2}$ generation bacteria with thermal and high acidity tolerance. The microbiota named OF-1 we use in this research was collected from soil samples. In addition, it can be cultured in high temperature as $60^{\circ} \mathrm{C}$ and acid atmosphere as $\mathrm{pH}$ 5.5. OF-1 includes the bacteria saccharifying cellulose and thermophilic bacteria generating $\mathrm{H}_{2}$.

\subsubsection{Test equipment}

The outline of test equipments in the laboratory is indicated in Fig.1. The volume of $\mathrm{H}_{2}$ fermenter (ABLE \& Biott Co.,Ltd., Japan) is $1 \mathrm{~L}$ and the effective volume is 600cc. Dilution materials adjusted to TS $7.5 \%$ are crushed by a food processor. The crushed dilution materials and additional minerals, e.g. $\mathrm{Ni}$ and $\mathrm{Co}$, were thrown into the fermenter. The additional minerals have arole to promote the methane fermentation. $\mathrm{NaOH}$ is used as $\mathrm{pH}$ control chemical. The residue of $\mathrm{H}_{2}$ fermentation is used as materials for $\mathrm{CH}_{4}$ fermentation. $\mathrm{CH}_{4}$ fermener (PRECI Co.,Ltd., Japan) has a car rier which is pumice stone. An operation of feeding materials and pulling up fermentation liquid is in the atmosphere.

The pilot plant flow is shown in Fig. 2. Kitchen wastes from our canteen are classified and crushed. They are mixed with crushed dog food and water. The materials are diluted to TS $6.5 \%$. The lower TS than laboratory test depends on a feeding ability of a pump. $\mathrm{pH}$ was adjusted to be $5.5 \mathrm{~b}$ y $\mathrm{Ca}(\mathrm{OH})_{2}$. A feeding and pulling up is anaerobic operation. Other experimental conditions are written in Table7.

The devices for analyzing the materials, biogas and fermentation liquid are as follows. Calorific values of materials are measured by a calorie meter EA6320 (Parr Instrument 
Company, U.S.). Elements are analyzed by an elemental analyzer Vario EL III (Elementar Americas, Inc. U.S.) . An absorption meter DR2800 (Hach Company, U.S.) measures COD. Biogas analysis is used by a gas chromatography GC-8A (Shimazu Corporation, Japan). Fermentation liquids are analyzed by a liquid chromatograph HPLC-20AD (Shimazu Corporation, Japan).

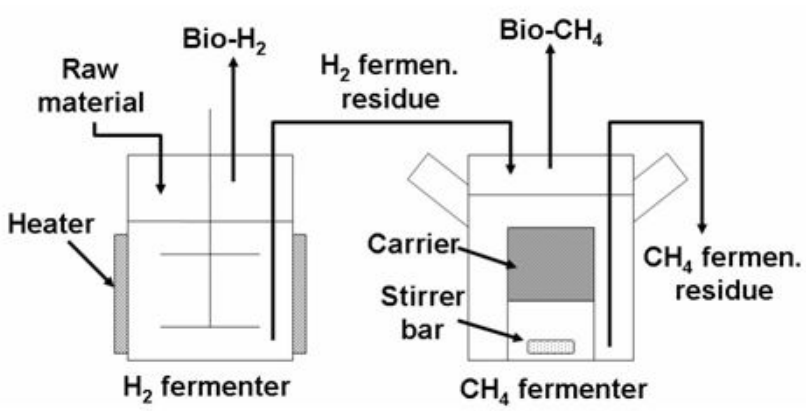

Fig. 1 Schematic diagram in the laboratory

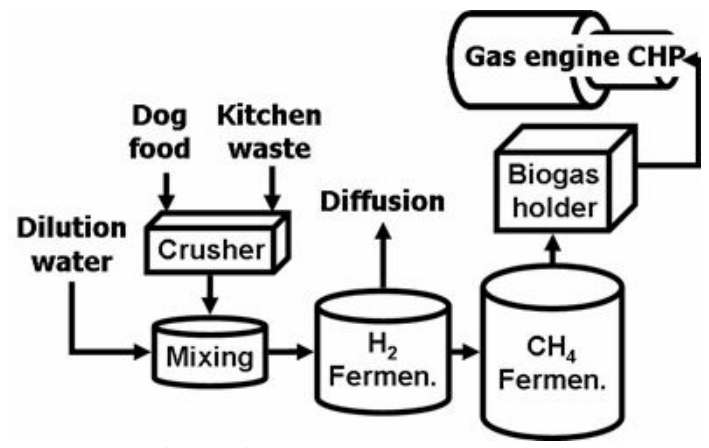

Fig. 2 Plant flow

Table 7 Experimental conditions

\begin{tabular}{|c|c|c|c|c|}
\hline Equipment & Laboratory & & Pilot plant & \\
\hline Fermentation & $\mathrm{H}_{2}$ & $\mathrm{CH}_{4}$ & $\mathrm{H}_{2}$ & $\mathrm{CH}_{4}$ \\
\hline Material & $\begin{array}{l}\text { Artificial kitchen } \\
\text { waste }\end{array}$ & $\begin{array}{l}\text { Residue of } \mathrm{H}_{2-} \\
\text { fermen. }\end{array}$ & $\begin{array}{l}\text { Kitchen waste } \\
\text { Dog food }\end{array}$ & $\begin{array}{l}\text { Residue of } \mathrm{H}_{2-} \\
\text { fermen. }\end{array}$ \\
\hline Feed & \multicolumn{4}{|c|}{1 feed / day (5days / week) } \\
\hline HRT (days) & $4.2,2.8$ & 14 & $4.2,2.8$ & 14 \\
\hline Volume & $600 \mathrm{cc}$ & $800 \mathrm{cc}$ & $0.4 \mathrm{Nm}^{3}$ & $4 \mathrm{Nm}^{3}$ \\
\hline Temp. $\left({ }^{\circ} \mathrm{C}\right)$ & 60 & 55 & 60 & 55 \\
\hline $\mathrm{pH}$ & 5.5(Controlled) & 7(Uncontrolled) & 5.5(Controlled) & 7(Uncontrolled) \\
\hline Carrier & $x$ & $\bigcirc$ & $x$ & $\bigcirc$ \\
\hline Stirring & Stirrer & Magnetic stirrer & Stirrer & $\begin{array}{l}\text { Stirrer } \\
\text { Circulation pump }\end{array}$ \\
\hline Varied sludge & $\begin{array}{l}\text { OF-1 } \\
\text { (Microbiota from } \\
\text { soil) }\end{array}$ & $\begin{array}{l}\text { Sludge of high } \\
\text { temp. } \mathrm{CH}_{4} \\
\text { fermen. }\end{array}$ & $\begin{array}{l}\text { OF-1 } \\
\text { (Microbiota } \\
\text { from soil) }\end{array}$ & $\begin{array}{l}\text { Sludge of high } \\
\text { temp. } \mathrm{CH}_{4} \text { fermen. }\end{array}$ \\
\hline
\end{tabular}

\section{Results}

\subsection{Laboratory test}

Figure 5 shows the time variation of bio- $\mathrm{H}_{2}$ volume. The stable and successive operation over 300 days was achieved. On the 350th day, the amount of feedstock was changed. Though HRT was shortened from $4.2 \mathrm{to} 2.8 \mathrm{da} y s$, the condition of $\mathrm{H}_{2}$ fermentation was well maintained and the stable running could be continued. But it is too difficult to realize shorter HRT. Because the feeding was once a weekday, in the perspective of only weekday, HRT is calculated as only 2 days. In the short HRT, $\mathrm{H}_{2}$ fermentation became unstable. The determined feeding on w eekday made the fluctuations of bio- $\mathrm{H}_{2}$ in the all run time. In beginning of the week, bio- $\mathrm{H}_{2}$ reduced and increased in weekend. The bands of fluctuation in the amount of bio- $\mathrm{H}_{2}$ became smaller as HRT shortening.

Though the materials and reactors were not sterilized, the density of lactic acid was under $2000 \mathrm{mg} / \mathrm{L}$ almost all the run time. A contamination was almost avoided since the operation 
temperature is high. $\mathrm{H}_{2}$ generation bacteria OF-1 has heat resistance, however, concentrated metabolites harm it. Figure 4 shows the relation between the density of lactic acid and the generated bio-hydrogen. The decrease in $\mathrm{H}_{2}$ was caused by the increase in the lactic acid. In this case we fed materials including large amount of lactic acid. The density control of lactic acid under $10000 \mathrm{mg} / \mathrm{L}$ is needed for efficient $\mathrm{H}_{2}$ fermentation.

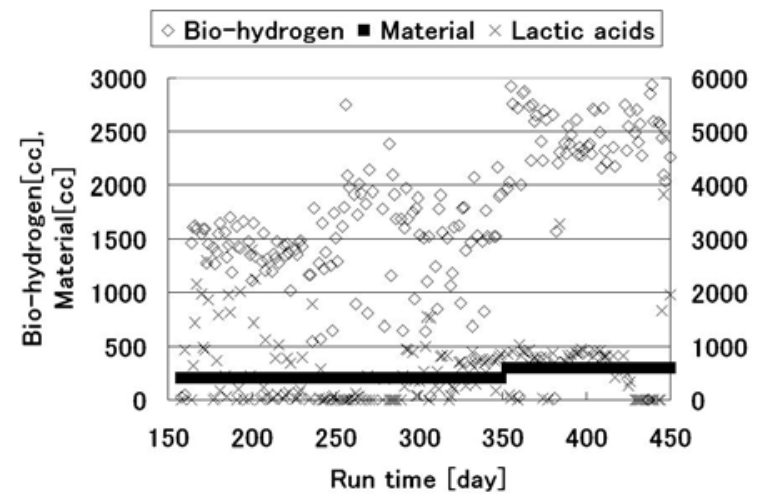

Fig.3 Generated bio-hydrogen

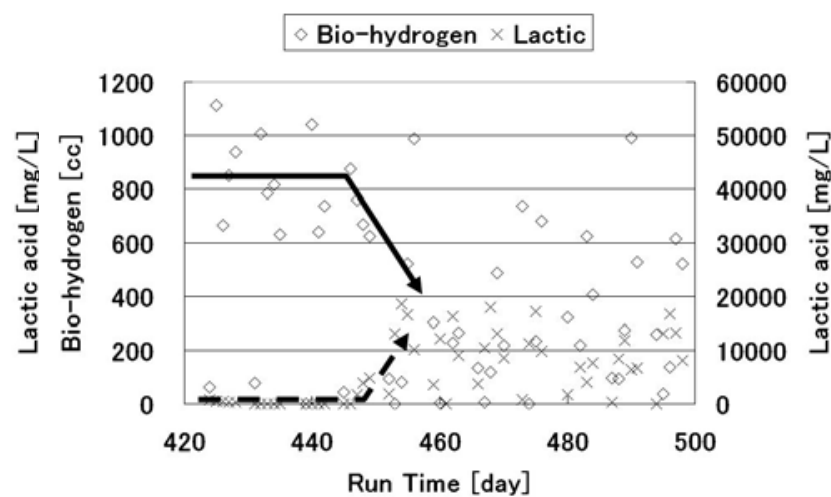

Fig.4 Increased lactic acid

Figure 7 shows the time variations of COD and VFA in the residue of $\mathrm{H}_{2}$ fermentation. The residue of $\mathrm{H}_{2}$ fermentation was a good substrate for methane fermentation since the residue contained much organic acids and the density of COD is suitable. The residue feeded into $\mathrm{CH}_{4}$ fermenter generated biogas including $\mathrm{CH}_{4}$ of $60 \%$. The energy recovery efficiency from biomass to bio- $\mathrm{H}_{2}$ and bio- $\mathrm{CH}_{4}$ is shown in Fig.6. The efficiency is the average value in one month. The efficiency was nearly $80 \%$, which was almost all derived from the generation of bio-methane. In this experimental condition, feeding and pulling up was operated in the atmosphere, therefore it is severe circumstances for anaerobic bacteria.

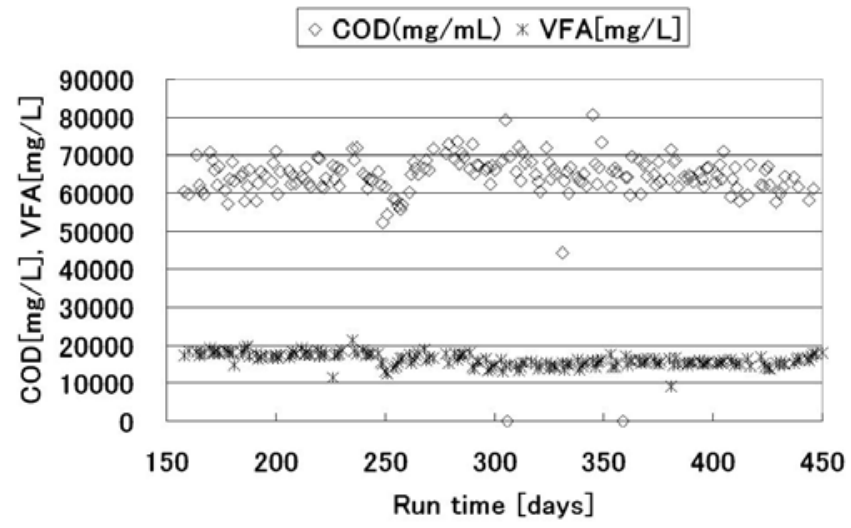

Fig. 5 COD-VFA in the residue of $\mathrm{H}_{2}$ fermen.

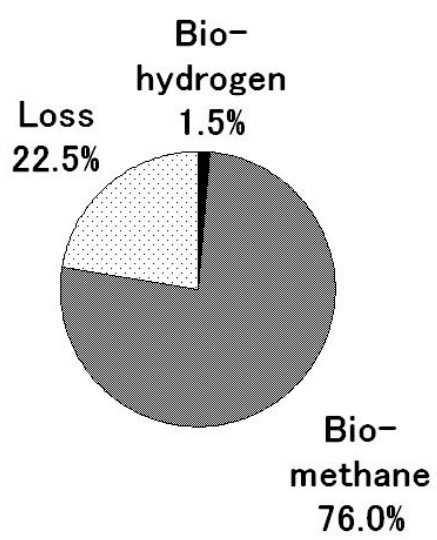

Fig. 6 Energy recovery in the laboratory

\subsection{Pilot plant test}

$\mathrm{H}_{2}-\mathrm{CH}_{4}$ fermentation was carried out in the pilot plant. Figure 7 shows the time variation of the generated bio-hydrogen. Stable operation continued over 150 days though the material injection was sometimes stopped. Kitchen wastes from the canteen were used in the pilot plant. Therefore feedstock was involved large amount of organic acids. Measured Lactic acid was about $1000-5000 \mathrm{mg} / \mathrm{L}$ in materials and $2000-8000 \mathrm{mg} / \mathrm{L}$ in the residue of $\mathrm{H}_{2}$ fermentation. The lactic acid density in the pilot plant test was higher than that in the 
laboratory test. The increased lactic acid affected $\mathrm{H}_{2}$ fermentation in the pilot plant compared with the results of the laboratory test. The concentration of lactic acid over $10000 \mathrm{mg} / \mathrm{L}$ prevents the generation of bio- $\mathrm{H}_{2}$. In the pilot plant, the density of lactic acid was scarcely kept under $10000 \mathrm{mg} / \mathrm{L}$.

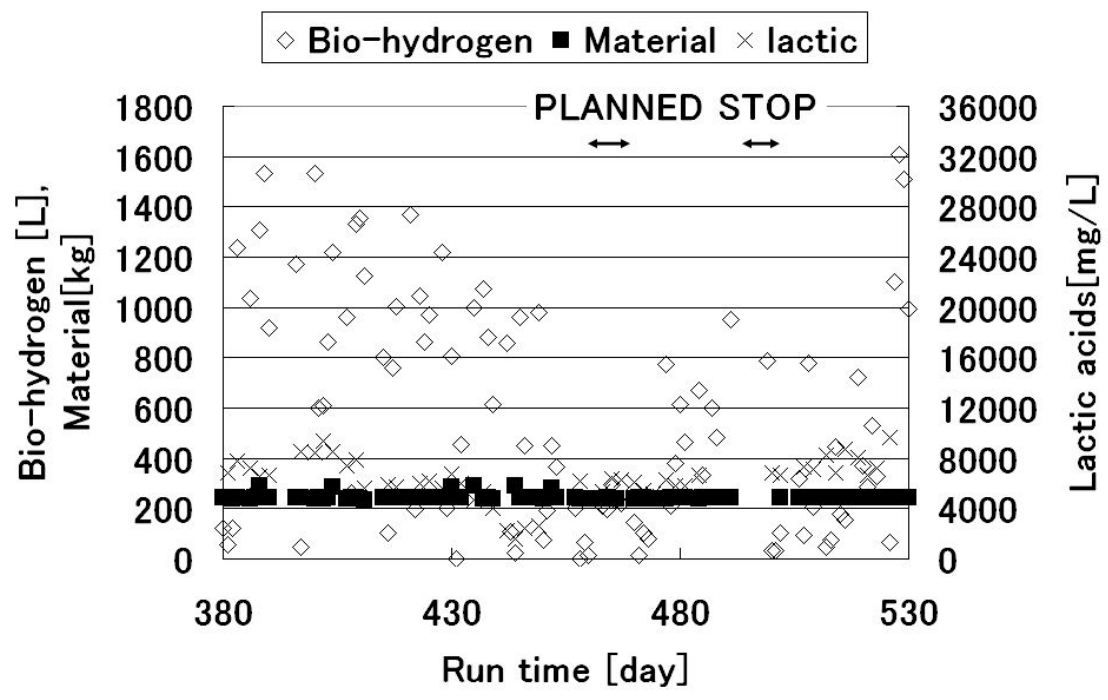

Fig. 7 Bio-hydrogen in the pilot plant

The residue of $\mathrm{H}_{2}$ fermentation was sent into the $\mathrm{CH}_{4}$ fermenter. The amount of bio-methane is indicated in Fig.8. Bio- $\mathrm{CH}_{4}$ was stably produced during the operation period.

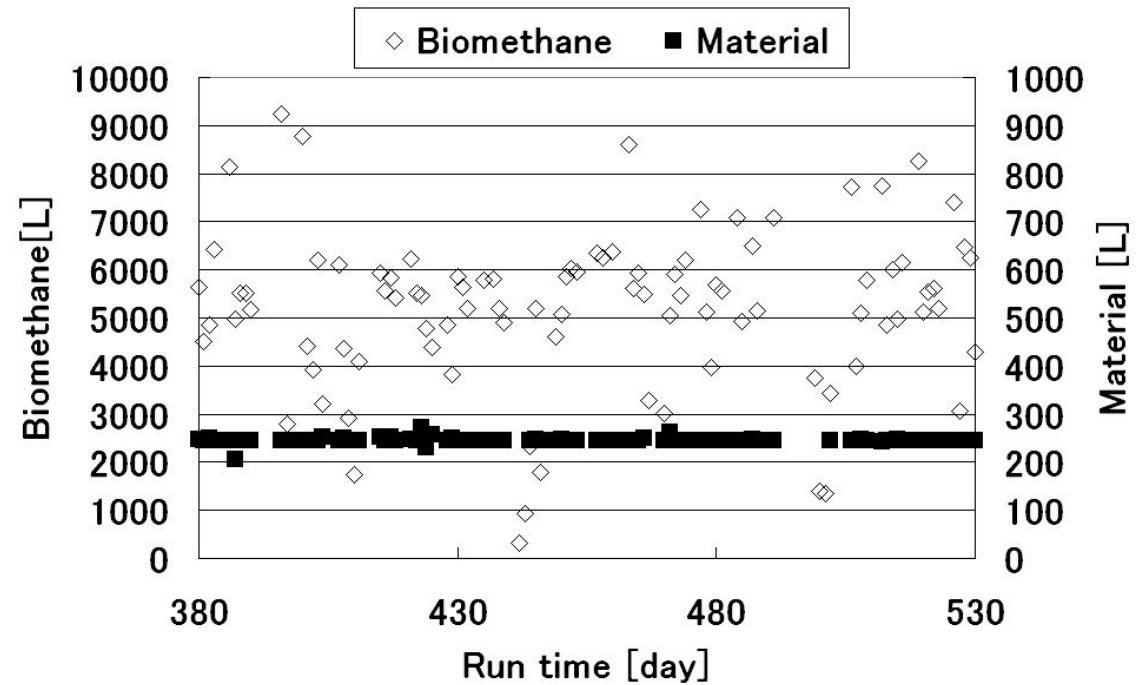

Fig. 8 Bio-methane in the pilot plant

Figure 9 shows the progress of energy recovery from materials in this pilot plant test. Almost all converted energy was the bio-methane as well as the laboratory test. The energy recovery efficiency was kept about $80 \%$ during the operated period. I In the same plant, another test was carried out, in which the oxidization was pretreated instead of the $\mathrm{H}_{2}$ fermentation. Figure 10 compares the recovery efficiency when the different pretreatment was conducted. Though the real kitchen wastes included lactic acid concentration and had contamination, the equal energy recovery was achieved. 


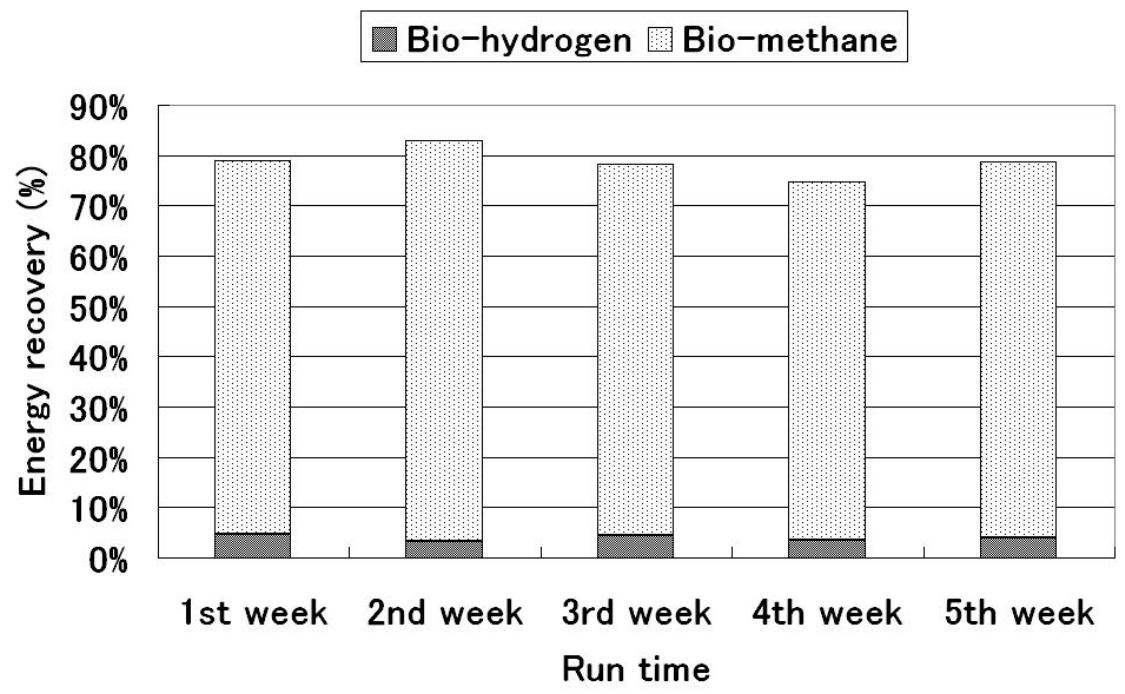

Fig. 9 Energy recovery
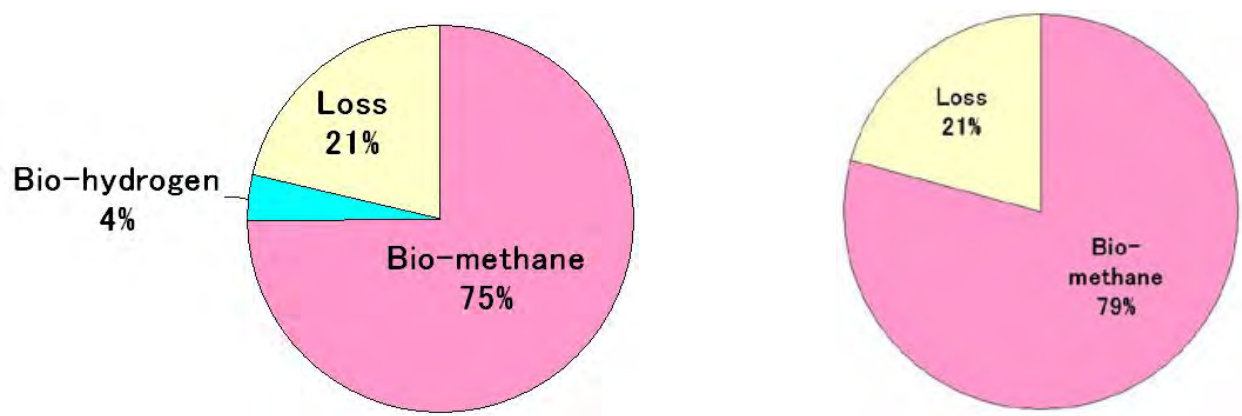

Fig. 10 Comparison of recovery efficiency

(Left: H2-CH4 fermentation, Right: Acidizing - CH4 fermentation)

\section{Conclusions}

OF-1 is determined to generate $\mathrm{H}_{2}$ in the environment which is high temperature and acidic. The stable operation in the $\mathrm{H}_{2}-\mathrm{CH}_{4}$ fermentation system was developed. Though metabolites generated by $\mathrm{H}_{2}$ fermentation harm the $\mathrm{H}_{2}$ generation bacteria itself, the running was stably kept due to high temperature operation and shortened HRT. The operation was stably conducted in 300 days in the laboratory and 150 days in the pilot plant. The residue of $\mathrm{H}_{2}$ fermentation was found to be good substrates for $\mathrm{CH} 4$ fermentation. The energy recovery efficiency in $\mathrm{H}_{2}-\mathrm{CH}_{4}$ fermentation was about $80 \%$. The efficiency value was equivalent to that of the acidizing $-\mathrm{CH}_{4}$ fermentation.

Future plan is aimed for increasing bio- $\mathrm{H}_{2}$ from the biomass consisted of cellulose. OF-1 includes cellulose decomposition bacteria. We will consider the possibility of disposing kitchen wastes with the biomass consisted of cellulose.

\section{Acknowledgement}

This research depends on the collaborative investigation with Toho Gas Co., LTD, and Mie University. I thank the concerned members. 


\section{References}

[1] F.R.Hawkes, et al., "Continuous Fermentation Hydrogen Production from a Wheat Starch Co-Product by Mixed Microflora", B iotechnology and Bioengineering vol.84 No.6 (2003)619-626

[2] Y.J.Lee, et al., "Effect of Iron Concentration on Hydrogen Fermentation", Bioresource Technology 80 (2001) 227-231

[3] Van Niel et al.,"Distinctive properties of Hugh producing extreme thermophiles Caldicellulosiruptor Saccharolyticus and Thermotoga elfii", International Journal of Hydrogen Energy 27(11-12) (2002) 1391-1398

[4] Van Niel et al., "Substrate and product inhabitation of hydrogen production by the thermophile, Caldicellulosiruptor sacharolyticus"in; Biotechnology and Bioengineering 81(3) (2003) 255-262 